\title{
Diurnal changes in large-bowel metabolism: short-chain fatty acids and transit time in rats fed on wheat bran
}

\author{
BY J. C. MATHERS AND J.-M. FOTSO TAGNY* \\ Department of Biological and Nutritional Sciences, University of Newcastle upon Tyne, \\ Newcastle upon Tyne, NE1 $7 R U$
}

(Received 18 December 1992 - Revised 22 March 1993 - Accepted 1 April 1993)

\begin{abstract}
To investigate diurnal changes in large-bowel metabolism rats were fed once daily on a cooked maizebased diet without or with $200 \mathrm{~g}$ wheat bran $/ \mathrm{kg}$ diet and containing $\mathrm{Cr}_{2} \mathrm{O}_{3}$ as an indigestible marker. After $17 \mathrm{~d}$ four rats on each diet were killed at 4, 10, 16 and $22 \mathrm{~h}$ postfeeding. Emptying of dry matter (DM) from the stomach occurred by an apparently zero-order process at about $0.5 \mathrm{~g} / \mathrm{h}$ in both diet groups. Feeding wheat bran had little effect on caecal pH or total short-chain fatty acid (SCFA) concentration but was associated with a marked increase in molar proportion of butyrate and a fall in propionate. There were substantial changes in caecal total SCFA concentration and in the molar proportions of individual SCFA throughout the day but no evidence of an interaction between diet and time interval after feeding. Caecal transit time (TT) was significantly reduced by feeding wheat bran whilst colonic TT was unaffected. Although when averaged across both diets there were no significant time effects on caecal or colonic TT, there was a significant diet $\times$ time interaction for caecal TT. The extent of coprophagy was measured. The proportion of stomach DM derived from ingested faeces increased with time interval after feeding but it was always a minor contribution so that in these circumstances coprophagy is unlikely to result in significant bias in estimates of digesta flow-rates or TT.
\end{abstract}

Large-bowel fermentation: Transit time: Wheat bran: Short-chain fatty acids

The rat is widely used as a model for man in studies of large-bowel metabolism that require invasive techniques and in evaluating food components or treatments which may not yet be licensed for human use. In some such studies the animals are fed once daily with measurements of large-bowel metabolism made at one time during the day, e.g. Goodlad \& Mathers (1990) and Mathers \& Dawson (1991). Thus, it is an implicit assumption of such studies that there is no diurnal variation in large-bowel metabolism (i.e. that dietary effects persist throughout the day) or, if there is, that changes occur similarly for all treatments. The occurrence of significant time interval after feeding $\times$ treatment interactions could have serious implications for the interpretation of data in the literature and for the design of future experiments.

In the present experiment rats were fed once daily on diets with and without wheat bran which is a rich source of non-starch polysaccharides (NSP) and known to alter both the bacterial endproducts of large-bowel fermentation (Cheng et al. 1987) and gastrointestinal transit time (TT; Müller-Lissner, 1988). Identical procedures were used to characterize large-bowel metabolism in animals killed 4, 10,16 and $22 \mathrm{~h}$ after feeding. The hypothesis to be tested in the present study was that the pattern of caecal short-chain fatty acids (SCFA) and estimates of TT, based on the indigestible marker $\mathrm{Cr}_{2} \mathrm{O}_{3}$, would be independent of the time of killing. It was anticipated that with once-daily feeding there would be marked diurnal variation in stomach contents, making estimates of TT for

\footnotetext{
* Present address: I.R.Z. - Mesires, PO Box 1457, Yaoundé, Cameroon.
} 
proximal gut compartments of limited value and focusing interest on the large bowel which may receive a more continuous input of digesta from the ileum. Validity of the calculation procedure for TT used in the present experiment (Faichney, 1975; Goodlad \& Mathers, 1987) requires that for the compartment under investigation the rates of marker inflow and outflow are approximately equal and constant (Warner, 1981). In addition, the procedure devised by Mathers \& Dawson (1991) was used to quantify coprophagy to enable the likely impact of this behaviour on estimates of digesta flow-rate through the gut and on TT to be assessed.

A preliminary account of part of the present study has been published (Mathers \& Fotso Tagny, 1989).

\section{MATERIALS AND METHODS}

\section{Diets and feeding}

Two diets based on cooked maize grain were prepared, with wheat bran (WB) included in one diet at the expense of sucrose, casein and egg albumen to maintain similar dietary protein concentrations (Table 1). $\mathrm{Cr}_{2} \mathrm{O}_{3}$ was included as an indigestible marker. Each animal was offered $15 \mathrm{~g}$ air-dry diet at 10.00 hours daily. Water was available ad lib.

\section{Animals, housing and experimental protocol}

Thirty-two male Wistar rats (initial weight $170-190 \mathrm{~g}$ ) were housed in individual metabolism cages (Thomson, 1970) and allocated at random to one of the experimental diets. After $10 \mathrm{~d}$ adaptation, food intake and faecal output were measured for $7 \mathrm{~d}$. Faeces were collected daily just before feeding and stored at $-20^{\circ}$ before freeze-drying. Animals were weighed at the beginning and end of this $7 \mathrm{~d}$ balance period.

Following this, four rats on each diet were slaughtered at 14.00, 20.00, 02.00 and 08.00 hours, i.e. 4, 10, 16, $22 \mathrm{~h}$ after presentation of the final meal. The stomach, small intestine (SI), caecum and colon were removed and weighed. Caecal $\mathrm{pH}$ was measured and a sample of contents removed for SCFA analysis. Samples of digesta were taken from the stomach, caecum and colon whilst the entire SI contents were flushed out using a syringe filled with distilled water. The empty gut compartments (excluding the SI) were washed, blotted dry and weighed. Tissue dry weights were obtained after freeze-drying.

\section{Analyses}

Caecal contents were deproteinized by mixing with metaphosphoric acid solution $(200 \mathrm{~g}$ $\mathrm{HPO}_{3} /$ l containing $50 \mathrm{~mm}-3$-methylvaleric acid as internal standard) and the supernatant fraction analysed for SCFA by packed column GLC (Mathers et al. 1990). $\mathrm{Cr}_{2} \mathrm{O}_{3}$ in diets, digesta and faeces was determined by atomic absorption spectrophotometry after dry ashing and solubilization of the $\mathrm{Cr}$ in the residue by heating with an acid mixture $(30 \mathrm{ml}$ $\mathrm{MnSO}_{4}$ solution $(100 \mathrm{~g} / \mathrm{l})$ diluted to 11 with $\left.15 \mathrm{M}-\mathrm{H}_{3} \mathrm{PO}_{4}\right)$ and $\mathrm{KBrO}_{3}\left(45 \mathrm{~g} \mathrm{KBrO}_{3} / 1\right)$ as described by Mathers et al. (1990). Organic matter was estimated by heating at $500^{\circ}$ for $16 \mathrm{~h}$.

\section{Calculations}

Apparent digestibility was calculated from total collections of food and faeces and by the marker ratio method. Caecal and colonic TT were calculated as the mass of $\mathrm{Cr}$ present in the organ divided by $\mathrm{Cr}$ intake rate (Faichney, 1975; Goodlad \& Mathers, 1987), i.e.

$$
\frac{\text { mass of DM in organ } \times \mathrm{Cr}_{2} \mathrm{O}_{3} \text { concentration in digesta DM }}{\text { daily food DM intake } \times \mathrm{Cr}_{2} \mathrm{O}_{3} \text { concentration in dietary DM }} \text {. }
$$

From concentrations of $\mathrm{Cr}$ in the diet, faeces and stomach contents, the proportion of 
Table 1. Composition of experimental diets

\begin{tabular}{llrr}
\hline \hline & Diet $\ldots$ & - WB & + WB \\
& Maize* & 600 & 600 \\
Wheat bran $\dagger$ & 0 & 200 \\
Casein & 55 & 40 \\
Egg albumen & 55 & 40 \\
Maize oil & 50 & 50 \\
Premix $\ddagger$ & 50 & 50 \\
Methionine & 3 & 3 \\
Tryptophan & 1 & 1 \\
Sucrose & 186 & 16 \\
\hline
\end{tabular}

-WB, without wheat bran; +WB, including wheat bran.

* Plate maize (Carlton Bros. Ltd., Seaton Delaval, Northumberland) autoclaved at $15 \mathrm{lb} / \mathrm{in}^{2}$ for $10 \mathrm{~min}$, dried at $60^{\circ}$ and ground to pass a $1 \mathrm{~mm}$ screen.

$\uparrow$ Ground to pass $1 \mathrm{~mm}$ screen.

\# Contained (g/kg premix): $\mathrm{CaHPO}_{4} 340, \mathrm{KCl} 62, \mathrm{NaCl} 26, \mathrm{MnSO}_{4} .7 \mathrm{H}_{2} \mathrm{O} 4, \mathrm{FeSO}_{4} .7 \mathrm{H}_{2} \mathrm{O} 1 \cdot 5, \mathrm{ZnSO}_{4} .7 \mathrm{H}_{2} \mathrm{O}$ $1 \cdot 1$, choline chloride 27 , and $\left(\mathrm{mg} / \mathrm{kg}\right.$ premix) $\mathrm{KI} 4, \mathrm{CuCl}_{2} \cdot 2 \mathrm{H}_{2} \mathrm{O} 160$, Rovimix $\mathrm{AD}_{3} 500 / 100$ (Roche) 200 , Rovimix E50 absorbate (Roche) 1200, niacin 400, calcium pantothenate 100, pteroylmonoglutamic acid 15 , menadione 10 , riboflavin 50 , thiamin 40 , pyridoxine 120 , cyanocobalamin 1 plus $40 \mathrm{~g} \mathrm{Cr}_{2} \mathrm{O}_{3} / \mathrm{kg}$ (as non-absorbed marker) and sucrose to make to $1 \mathrm{~kg}$.

stomach DM derived from the diet (as distinct from ingested faeces) was determined (Mathers \& Dawson, 1991) as:

$$
\frac{S-F}{D-F}
$$

where $D, S, F$ are concentrations of $\mathrm{Cr}_{2} \mathrm{O}_{3}$ in DM of the diet, stomach contents and faeces respectively. We have recently become aware that a similar procedure was used by Gidenne $\&$ Poncet (1985) to make quantitative estimates of caecotrophy in the rabbit.

\section{Statistical procedures}

Data were examined by two-way analysis of variance with diets and time of killing as the two factors. Responses to time of killing were described by orthogonal polynomials. In some cases, whilst overall effects of time or diet $\times$ time were not significant $(P>0.05)$, one of the orthogonal components of these factors was significant and when this occurred mention is made in the text.

\section{RESULTS}

Food intake, growth rate and digestibility of diets

Virtually all the food offered was eaten by all animals and the $2.7 \mathrm{~g}$ difference in DM intake over the $7 \mathrm{~d}$ balance period (Table 2) is due to the higher DM content of the diet without WB ( $-\mathrm{WB}$; 931 v. $908 \mathrm{~g} \mathrm{DM} / \mathrm{kg}$ diet for $-\mathrm{WB}$ and $+\mathrm{WB}$ diets respectively). Animals consuming the + WB diet gained only 0.77 of the body weight of those fed on the - WB diet as a consequence of the lower DM intake but also of the reduced digestibility of the + WB diet (Table 2). Faecal DM output was more than doubled by including WB in the diet. The proportion of orally-administered $\mathrm{Cr}_{2} \mathrm{O}_{3}$ recovered in faeces was similar for both diets (1.09 and 1.07 (SE 0.013) for $-\mathrm{WB}$ and $+\mathrm{WB}$ respectively) and there was little difference in apparent digestibility whether calculated by the total collection or marker ratio method (Table 2 ). 
Table 2. Intake, faecal output, digestibility and live-weight gain by rats given cookedmaize-based diets without $(-W B)$ or with $200 \mathrm{~g}$ wheat bran $/ \mathrm{kg}$ diet $(+W B) \dagger$

(Means for sixteen rats per diet)

\begin{tabular}{|c|c|c|c|c|}
\hline Diet... & $-W B$ & $+W B$ & SEM & $\begin{array}{l}\text { Statistical } \\
\text { significance } \\
\text { of diet effect }\end{array}$ \\
\hline DM intake $(\mathrm{g} / 7 \mathrm{~d})$ & $97 \cdot 1$ & $94 \cdot 4$ & $0 \cdot 045$ & $* * *$ \\
\hline Faecal DM output (g/7 d) & $7 \cdot 7$ & $15 \cdot 3$ & $0 \cdot 15$ & $* * *$ \\
\hline $\begin{array}{l}\text { Faecal DM output (g/kg DM } \\
\text { intake) }\end{array}$ & 79 & 162 & $1 \cdot 5$ & $* * *$ \\
\hline \multicolumn{5}{|l|}{ Apparent digestibility } \\
\hline DM & 0.927 & 0.848 & $0 \cdot 0014$ & $* * *$ \\
\hline $\mathrm{DM} \ddagger$ & 0.921 & 0.838 & 0.0014 & $* * *$ \\
\hline$O M$ & 0.927 & 0.848 & 0.0012 & $* * *$ \\
\hline Ash & $0 \cdot 868$ & 0.794 & 0.0056 & $* * *$ \\
\hline Wt gain $(g / 7 d)$ & $36 \cdot 9$ & $28 \cdot 5$ & $0 \cdot 87$ & $* * *$ \\
\hline
\end{tabular}

DM, dry matter; OM, organic matter.

*** $P<0.001$.

$\dagger$ For details of diet composition, see Table 1.

+ Marker ratio method was used to calculate digestibility; all other digestibilities were calculated by total collection method.

\section{Gastrointestinal organ masses}

When averaged over all killing times, rats fed on WB had heavier gut compartments (significantly so for the stomach and colon; Table 3 ) There was no convincing evidence that feeding WB increased gut tissue masses (indeed, there was significantly less caecal tissue $\mathrm{DM}$ for the $+\mathrm{WB}$ rats; Table 4) so that the greater gut weights could be attributed to more digesta. For the stomach, caecum and colon, feeding WB was associated with a higher water content in digesta and only for the colon was significantly more DM recovered in + WB animals (Table 3).

For stomach and SI, several variables showed significant diet $\times$ time interactions (Table 3). At $4 \mathrm{~h}$ after feeding, the stomachs of $+\mathrm{WB}$ rats were heavier, because of larger amounts of digesta, than those of - WB rats. With time there was a significant $(P<0 \cdot 001)$ curvilinear decline so that by $22 \mathrm{~h}$ after feeding only traces of digesta remained in the stomach for both diet groups. The proportions of DM in stomach digesta fell with time interval after feeding for $-\mathrm{WB}$ rats but remained constant (and lower) for the $+\mathrm{WB}$ rats. SI weight for the $-\mathrm{WB}$ animals increased between 4 and $10 \mathrm{~h}$ post-feeding and then declined, whereas in the + WB group SI mass was greatest at $4 \mathrm{~h}$ and declined thereafter.

There were no significant diet $\times$ time interactions for the caecum or colon. For the caecum the masses of the whole organ, tissue and wet digesta changed quadratically with time interval after feeding, with peaks at about $10 \mathrm{~h}$. Trends for the colon were similar but the effects were not significant because of greater inter-animal variation. Colonic digesta tended to increase in moisture content $(\mathrm{P}<0.05)$ with time interval after feeding, especially for the -WB group.

\section{Caecal fermentation}

Although not statistically significant, caecal $\mathrm{pH}$ tended to be lower in $+\mathrm{WB}$ animals (Table 5). There was a significant $(P<0.05)$ quadratic response in caecal $\mathrm{pH}$ with lowest values $10-16 \mathrm{~h}$ following feeding and values at $22 \mathrm{~h}$ slightly higher than at $4 \mathrm{~h}$. Total SCFA 
Table 3. Gastrointestinal organ and contents weights from rats given cooked-maize-based diets without $(-W B)$ or with $200 \mathrm{~g}$ wheat bran $/ \mathrm{kg}$ diet $(+W B) \dagger$

(Means for four rats per treatment)

\begin{tabular}{|c|c|c|c|c|c|c|c|c|c|c|c|c|}
\hline \multirow{3}{*}{$\begin{array}{l}\text { Diet... } \\
\text { Time (h) after feeding... }\end{array}$} & \multirow{2}{*}{\multicolumn{4}{|c|}{$-W B$}} & \multirow{2}{*}{\multicolumn{4}{|c|}{$+W B$}} & \multirow[b]{3}{*}{ SEM } & \multicolumn{3}{|c|}{$\begin{array}{l}\text { Statistical } \\
\text { significance } \\
\text { of effects of: }\end{array}$} \\
\hline & & & & & & & & & & & & \\
\hline & 4 & 10 & 16 & 22 & 4 & 10 & 16 & 22 & & (D) & ( $\mathrm{T})$ & $\mathrm{D} \times \mathrm{T}$ \\
\hline \multicolumn{13}{|l|}{ Stomach } \\
\hline Total organ (g) & $20 \cdot 7$ & $9 \cdot 8$ & $5 \cdot 1$ & 1.9 & $24 \cdot 2$ & $10 \cdot 6$ & $5 \cdot 0$ & $1 \cdot 8$ & 0.53 & $* *$ & $* * *$ & $* *$ \\
\hline Digesta wet wt (g) & $19 \cdot 3$ & $8 \cdot 5$ & $3 \cdot 6$ & 0.3 & $22 \cdot 7$ & $9 \cdot 1$ & $3 \cdot 6$ & 0.4 & 0.52 & $*$ & $* * *$ & $* *$ \\
\hline Digesta dry wt (g) & $9 \cdot 3$ & $3 \cdot 8$ & $1 \cdot 4$ & + & $8 \cdot 4$ & $3 \cdot 6$ & $1 \cdot 3$ & $\ddagger$ & $0 \cdot 26$ & NS & $* * *$ & NS \\
\hline Proportion of DM in digesta & 0.48 & $0 \cdot 45$ & $0 \cdot 38$ & $\dot{t}$ & $0 \cdot 37$ & 0.39 & $0 \cdot 37$ & $\ddagger$ & $0 \cdot 011$ & $* * *$ & $* * *$ & $* * *$ \\
\hline \multicolumn{13}{|l|}{ Small intestine } \\
\hline Total organ $(\mathrm{g})$ & $7 \cdot 7$ & $8 \cdot 5$ & $8 \cdot 3$ & 69 & $9 \cdot 3$ & $9 \cdot 0$ & $7 \cdot 9$ & $6 \cdot 5$ & $0 \cdot 35$ & NS & $* * *$ & * \\
\hline Digesta dry wt (g) & 0.52 & $0 \cdot 43$ & $0 \cdot 44$ & 0.21 & 0.86 & 0.80 & $0 \cdot 58$ & 026 & $0 \cdot 039$ & $* * *$ & $* * *$ & $* * *$ \\
\hline \multicolumn{13}{|l|}{ Caecum } \\
\hline Tolal organ (g) & $3 \cdot 96$ & $4 \cdot 49$ & 3.85 & 3.45 & 3.63 & 4.57 & $4 \cdot 10$ & 3.76 & 0.233 & NS & ** & NS \\
\hline Digesta wet wt (g) & $3 \cdot 02$ & $3 \cdot 56$ & $2 \cdot 86$ & $2 \cdot 60$ & $2 \cdot 70$ & $3 \cdot 64$ & $3 \cdot 22$ & $2 \cdot 88$ & $0 \cdot 211$ & NS & $* *$ & NS \\
\hline Digesta dry wt (g) & $0 \cdot 64$ & $0 \cdot 87$ & $0 \cdot 70$ & 0.62 & 0.55 & 0.75 & 0.67 & $0 \cdot 59$ & $0 \cdot 061$ & NS & $* *$ & NS \\
\hline Proportion of DM in digesta & $0 \cdot 21$ & $0 \cdot 24$ & $0 \cdot 25$ & $0 \cdot 24$ & $0 \cdot 20$ & 0.21 & $0 \cdot 21$ & $0 \cdot 20$ & 0.009 & $* * *$ & NS & NS \\
\hline \multicolumn{13}{|l|}{ Colon } \\
\hline Total organ $(\mathrm{g})$ & $3 \cdot 20$ & $4 \cdot 11$ & $2 \cdot 53$ & $2 \cdot 96$ & $3 \cdot 89$ & $4 \cdot 04$ & $3 \cdot 82$ & $4 \cdot 36$ & 0.428 & $*$ & NS & NS \\
\hline Digesta wet wt (g) & 1.90 & $2 \cdot 37$ & 1.50 & $1 \cdot 30$ & $2 \cdot 42$ & 2.54 & $2 \cdot 51$ & $2 \cdot 80$ & $0 \cdot 373$ & * & NS & NS \\
\hline Digesta dry wt (g) & $0 \cdot 84$ & $1 \cdot 02$ & 0.60 & 0.61 & 0.93 & 0.94 & 0.79 & 1.04 & $0 \cdot 162$ & $\mathrm{NS}$ & NS & NS \\
\hline Proportion of DM in digesta & $0 \cdot 44$ & 0.43 & $0 \cdot 40$ & 0.37 & 0.38 & 0.38 & 0.32 & 0.37 & 0.019 & $* * *$ & $*$ & NS \\
\hline
\end{tabular}

DM, dry matter; NS, not significant.

$* P<0.05,{ }^{* *} P<0.01,{ }^{* * *} P<0.001$.

$\dagger$ For details of diet composition. see Table 1 .

Insufficient sample for analysis.

Table 4. Gut tissue weights in rats given cooked-maize-based diets without $(-W B)$ or with $200 \mathrm{~g}$ wheat bran $/ \mathrm{kg}$ diet $(+W B) \dagger$

(Means for sixteen rats per diet)

\begin{tabular}{|c|c|c|c|c|}
\hline Diet... & $-W B$ & $+W B$ & SEM & $\begin{array}{c}\text { Statistical significance } \\
\text { of diet effect }\end{array}$ \\
\hline \multicolumn{5}{|l|}{ Tissue wet wt $(\mathrm{g})$} \\
\hline Stomach & $1 \cdot 44$ & 1.47 & $0 \cdot 026$ & NS \\
\hline Caecum & 0.93 & 0.91 & $0 \cdot 017$ & NS \\
\hline Colon & $1 \cdot 35$ & 1.46 & 0.047 & NS \\
\hline \multicolumn{5}{|l|}{ Tissue dry wt (g) } \\
\hline Stomach & $0 \cdot 36$ & $0 \cdot 35$ & 0.008 & NS \\
\hline Small intestine & $1 \cdot 57$ & 1.54 & $0 \cdot 140$ & NS \\
\hline Caecum & $0 \cdot 25$ & $0 \cdot 22$ & $0 \cdot 007$ & $* *$ \\
\hline Colon & $0 \cdot 34$ & $0 \cdot 37$ & 0.017 & NS \\
\hline
\end{tabular}

NS, not significant.

** $P<0.01$

$\dagger$ For details of diet composition, see Table 1. 
Table 5. Digesta $p H$ and concentrations, molar proportions and pool sizes of short-chain fatty acids $(S C F A)$ in the caecum of rats given cooked-maize-based diets without $(-W B)$ or with $200 \mathrm{~g}$ wheat bran $/ \mathrm{kg}$ diet $(+W B) \dagger$

(Means for four rats per treatment)

\begin{tabular}{|c|c|c|c|c|c|c|c|c|c|c|c|c|}
\hline \multirow{3}{*}{$\begin{array}{l}\text { Diet ... } \\
\text { Time-interval (h) } \\
\text { after feeding... }\end{array}$} & \multirow{2}{*}{\multicolumn{4}{|c|}{$-W B$}} & \multirow{2}{*}{\multicolumn{4}{|c|}{+ WB }} & \multirow[b]{3}{*}{ SEM } & \multicolumn{3}{|c|}{$\begin{array}{l}\text { Statistical signifi- } \\
\text { cance of effects }\end{array}$} \\
\hline & & & & & & & & & & \multirow{2}{*}{$\begin{array}{l}\text { Diet } \\
\text { (D) }\end{array}$} & \multirow{2}{*}{$\begin{array}{l}\text { Time } \\
\text { (T) }\end{array}$} & \multirow[b]{2}{*}{$\mathrm{D} \times \mathrm{T}$} \\
\hline & 4 & 10 & 16 & 22 & 4 & 10 & 16 & 22 & & & & \\
\hline $\mathrm{pH}$ & $6 \cdot 1$ & $5 \cdot 9$ & $5 \cdot 9$ & $6 \cdot 2$ & 59 & $5 \cdot 7$ & $6 \cdot 0$ & $6 \cdot 1$ & $0 \cdot 11$ & NS & * & NS \\
\hline $\begin{array}{l}\text { Total SCFA (mmol } / \mathrm{kg} \\
\text { caecal contents) }\end{array}$ & 156 & 165 & 153 & 108 & 159 & 155 & 133 & 123 & $8 \cdot 6$ & NS & $* * *$ & NS \\
\hline \multicolumn{13}{|l|}{$\begin{array}{l}\text { Molar proportions of } \\
\text { individual SCFA } \\
(\mathrm{mmol} / \mathrm{mol})\end{array}$} \\
\hline Acetate & 632 & 648 & 641 & 617 & 636 & 654 & 632 & 583 & $18 \cdot 2$ & NS & NS & NS \\
\hline Propionate & 217 & 191 & 208 & 170 & 137 & 128 & 142 & 143 & $13 \cdot 6$ & $* * *$ & NS & NS \\
\hline Isobutyrate & 17 & 15 & 10 & 16 & 15 & 11 & 14 & 14 & $2 \cdot 3$ & NS & NS & NS \\
\hline Butyrate & 102 & 118 & 112 & 157 & 184 & 183 & 182 & 220 & $12 \cdot 8$ & $* * *$ & $* *$ & NS \\
\hline Isovalerate & 17 & 14 & 13 & 24 & 18 & 13 & 19 & 26 & $2 \cdot 4$ & NS & $* * *$ & NS \\
\hline Valerate & 16 & 15 & 16 & 16 & 10 & 10 & 12 & 13 & $1 \cdot 2$ & $* * *$ & NS & NS \\
\hline \multicolumn{13}{|l|}{ SCFA pool $(\mu \mathrm{mol} / \mathrm{rat})$} \\
\hline Acetate & 298 & 374 & 284 & 172 & 272 & 369 & 273 & 207 & $24 \cdot 8$ & NS & $* * *$ & NS \\
\hline Propionate & 102 & 116 & 94 & 47 & 60 & 73 & 62 & 51 & $14 \cdot 2$ & $* *$ & $*$ & NS \\
\hline Isobutyrate & 8 & 9 & 5 & 5 & 7 & 6 & 6 & 5 & $1 \cdot 3$ & NS & NS & NS \\
\hline Butyrate & 48 & 69 & 48 & 45 & 80 & 104 & 78 & 78 & $8 \cdot 6$ & $* * *$ & $*$ & NS \\
\hline Isovalerate & 8 & 8 & 6 & 7 & 8 & 7 & 8 & 9 & $1 \cdot 3$ & NS & NS & NS \\
\hline Valerate & 8 & 9 & 7 & 5 & 4 & 6 & 5 & 5 & $0 \cdot 9$ & $* *$ & NS & NS \\
\hline Total SCFA & 471 & 584 & 444 & 281 & 430 & 566 & $43 !$ & 355 & $45 \cdot 2$ & NS & $* * *$ & NS \\
\hline
\end{tabular}

NS, not significant.

$* P<0.05, * * P<0.01, * * * P<0.001$.

$\uparrow$ For details of diet composition, see Table 1 .

Table 6. Transit times $(h)$ of the marker chromic oxide in the large bowel of rats given cooked-maize-based diets without $(-W B)$ or with $200 \mathrm{~g}$ wheat bran/kg diet $(+W B) \dagger$

(Means for four rats per treatment)

\begin{tabular}{|c|c|c|c|c|c|c|c|c|c|c|c|c|}
\hline \multirow{2}{*}{$\begin{array}{l}\text { Diet ... } \\
\text { Time-interval (h) } \\
\text { after feeding... }\end{array}$} & \multicolumn{4}{|c|}{$-W B$} & \multicolumn{4}{|c|}{$+W B$} & \multirow[b]{2}{*}{ SEM } & \multicolumn{3}{|c|}{$\begin{array}{l}\text { Statistical significance } \\
\text { of effects of: }\end{array}$} \\
\hline & 4 & 10 & 16 & 22 & 4 & 10 & 16 & 22 & & Diet (D) & Time (T) & $\mathrm{D} \times \mathrm{T}$ \\
\hline Caecum & $11 \cdot 3$ & $15 \cdot 0$ & $12 \cdot 4$ & $11 \cdot 1$ & $8 \cdot 4$ & $8 \cdot 4$ & $7 \cdot 6$ & $7 \cdot 1$ & $1 \cdot 32$ & $* * *$ & NS & $*$ \\
\hline Colon & $13 \cdot 7$ & $17 \cdot 5$ & $11 \cdot 0$ & $11 \cdot 8$ & $12 \cdot 9$ & 13.3 & $9 \cdot 5$ & $11 \cdot 7$ & 2.09 & NS & NS & NS \\
\hline Large bowel & $25 \cdot 0$ & $32-5$ & $23 \cdot 4$ & $22 \cdot 9$ & $21 \cdot 3$ & $21 \cdot 7$ & $17 \cdot 1$ & $18 \cdot 8$ & $2 \cdot 15$ & $* * *$ & $*$ & NS \\
\hline
\end{tabular}

NS, not significant.

${ }^{*} P<0.05 ; * * * P<0.001$.

$\dagger$ For details of diet composition, see Table 1.

concentration showed the opposite response with a peak $(160 \mathrm{mmol} / \mathrm{kg}$ caecal contents) at $10 \mathrm{~h}$ postfeeding falling to $115 \mathrm{mmol} / \mathrm{kg}$ caecal contents at $22 \mathrm{~h}$. Consumption of WB was accompanied by marked changes in the relative proportions of caecal SCFA, with a $57 \%$ increase in butyrate and reductions of 43 and $40 \%$ in propionate and valerate 


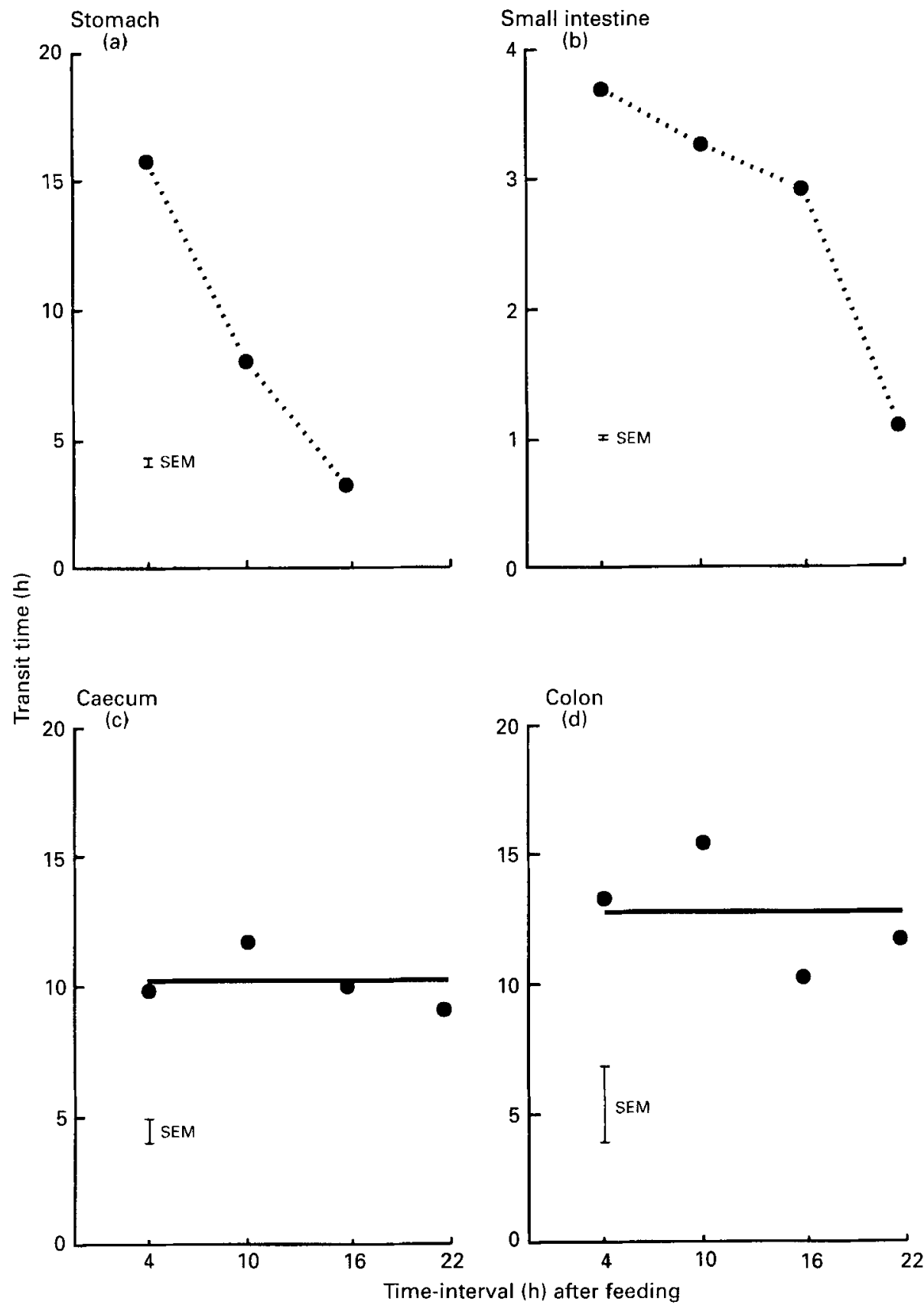

Fig. 1. Estimates of transit time through the $(a)$ stomach, $(b)$ small intestine, $(c)$ caecum and $(d)$ colon of rats from measurements made at various time-intervals after feeding. Points are means for eight animals consuming diets with and without $200 \mathrm{~g}$ wheat bran $/ \mathrm{kg}$ diet. For details of diet composition, see Table $\mathrm{l}$.

respectively. When averaged across both diets, molar proportion of acetate showed a quadratic $(P<0.05)$ response with time interval after feeding, peaking around $10 \mathrm{~h}$, isovalerate showed the opposite response, whilst the molar proportion of butyrate increased linearly $(P<0.01)$ with time. 
Caecal SCFA pool sizes were calculated as the product of SCFA concentrations (Table 5 ) and wet weight of contents (Table 3$)$. There were no significant $(P>0.05)$ diet $\times$ time interactions for these variables. At peak ( $10 \mathrm{~h}$ postfeeding) the caecum of each rat contained almost $0.6 \mathrm{mmol}$ SCFA, but values were about $50 \%$ lower at $22 \mathrm{~h}$ after feeding. This curvilinear response was seen with each of the major acids (acetate, propionate and butyrate) but time effects were not significant $(P>0.05)$ for isobutyrate, isovalerate and valerate. On average, rats fed on WB had a caecal butyrate pool 1.62 times that of the - WB group but only 0.69 of their propionate pool size.

\section{Large-bowel transit time}

Rats fed on WB had caecal TT which were on average $37 \%$ less than those on diet - WB (Table 6). There was a significant $(P<0.05)$ diet $\times$ time effect for caecal TT with rats fed on diet -WB having a prolonged TT at $10 \mathrm{~h}$ after feeding compared with other times, whilst there was no significant effect of time for the WB-fed animals. Colonic TT was similar to that for the caecum for the -WB group but greater for the colon than for the caecum for + WB animals. Diurnal changes in colonic TT tended to be similar to those seen in the caecum but none of the effects was statistically significant. For the whole large bowel (caecum + colon), TT was, on average, $6 \mathrm{~h}$ longer for the $-\mathrm{WB}$ rats $(P<0.001)$ with diet means $(\mathrm{h})$ of $26.0(-\mathrm{WB})$ and $19 \cdot 8(+\mathrm{WB})$. There was no significant diet $\times$ time interaction but, when averaged across both diets, large-bowel TT showed a significant curvilinear relationship with time interval after feeding $(F(1,24)$ for cubic effect was $7 \cdot 35 ; P<0 \cdot 025)$ with the greatest TT at $10 \mathrm{~h}$ postfeeding.

\section{Coprophagy}

There was sufficient digesta in the stomach at 4,10 and $16 \mathrm{~h}$ after feeding to allow estimation of $\mathrm{Cr}_{2} \mathrm{O}_{3}$ concentration and, therefore, calculation of the proportion of stomach contents DM which was derived directly from ingested food using the procedure described by Mathers \& Dawson (1991). At the earliest killing time ( $4 \mathrm{~h}$ after feeding) virtually all the DM (mean 1.00, range 0.99-1.02) was derived directly from ingested food and, although this proportion declined with time, by $16 \mathrm{~h}$ postfeeding this proportion had only fallen to 0.95 (range $0.91-0.99$; Fig. 1). There were no significant effects of diet but there was a significant diet $\times$ time interaction, i.e. $(-W B v .+W B) \times$ linear effect of time was significant $(P<0.05)$, indicating a greater proportion of faecal matter in the stomach at later times in the WB-fed rats.

\section{DISCUSSION}

Digestion and growth

It is clearly established that adding WB to the diet increases stool mass of both wet and dry matter (Cummings et al. 1976a; Müller-Lissner, 1988) through increased output of undigested dietary fragments and associated water, colonic-derived bacterial cells and possibly endogenous materials (Wisker \& Feldheim, 1992). In the present study, feeding WB doubled faecal DM output (Table 2). Feeding WB resulted in an extra $8.3 \mathrm{~g}$ faecal $\mathrm{DM} / 100 \mathrm{~g}$ diet DM consumed or $0.43 \mathrm{~g}$ extra faecal DM/g WB DM consumed. This is a much smaller increase in faecal DM than has frequently been reported in healthy human subjects given WB. From the review by Müller-Lissner (1988) of eight studies where WB was fed to normal volunteers it may be calculated that the extra stool voided during WB consumption periods corresponded to 0.95 (SD 0.309) g extra faecal DM/g WB DM consumed, assuming that human stool contains $0.23 \mathrm{~g} \mathrm{DM} / \mathrm{g}$ (Stephen et al. 1986) and that WB contains $0.89 \mathrm{~g} \mathrm{DM} / \mathrm{g}$. In four of the eight studies reviewed by Müller-Lissner (1988) the extra faecal DM exceeded the DM of the WB consumed. Since digestibility of food 
macromolecules including refractory substances such as NSP (Nyman et al. 1986) are usually considered to be very similar in rat and man, this apparent divergence in handling WB merits further investigation.

If it is assumed that the dietary components replaced by WB in the present study, i.e. sucrose, casein and egg albumen, had digestibilities of 1.00, then the apparent digestibility of the WB was approximately 0.6 . Since the apparent digestibility of the NSP fraction of WB is approximately 0.4 (van Dokkum et al. 1983; Nyman et al. 1986; Stephen et al. 1986) and NSP accounts for about 0.4 of WB (Holland et al. 1991), it may be calculated that the apparent digestibility of the non-NSP portion of WB, consisting mainly of starch, protein and lipid, was about $0 \cdot 7$. It is likely that the large bowel was the site of digestion of all the NSP (Englyst \& Cummings, 1985) and at least some of the other WB components. Whilst the SCFA absorbed following large-bowel fermentation are a useful additional source of energy, this salvage mechanism recovers only about 0.5 of the energy which would be gained by digestion of carbohydrate in the small intestine (Livesey, 1990; Mathers, 1991). Thus, the poorer weight gains of the rats fed on WB (Table 2) are probably due to lower absorption of energy because of reduced diet digestibility and a distal shift in site of digestion in addition to the small reduction in DM consumption.

\section{Large-bowel fermentation}

Although adding WB increased the NSP content of the diet by about $80 \mathrm{~g} / \mathrm{kg}$, there was only a small, non-significant fall in caecal $\mathrm{pH}$ (Table 5), probably because WB is relatively slowly fermented in the large bowel. Since the digestibility of the more refractory components of the NSP fraction is most sensitive to alterations in TT (Stephen et al. 1987; Mathers, 1991), the reduced caecal TT which accompanied WB feeding may have prevented more extensive fermentation. The present study confirmed that WB consumption provokes a major change in SCFA pattern with a substantial increase in butyrate (Walter et al. 1986, 1988; Cheng et al. 1987) at the expense of propionate. Possible reasons for alterations in the molar proportions of the major SCFA have been explored elsewhere (Goodlad \& Mathers, 1990; Mathers \& Dawson, 1991; Mathers et al. 1993). Macfarlane (1991) has suggested that colonic bacteria divert $\mathrm{C}$ to the synthesis of butyrate rather than the more energetically favourable acetate in conditions of substrate (carbohydrate) excess because butyrate acts as a $\mathrm{H}$ sink so allowing regeneration of reduced dinucleotides and permitting glycolysis to proceed. Compared with the -WB group, bacteria in the caecum of WB-fed rats will have been supplied with considerably more substrate and, given the much shorter caecal TT for these animals, it is probable that there was a relative excess of carbohydrate so the explanation of Macfarlane (1991) may apply in this case.

In many studies of large-bowel fermentation animals have been fed once daily and sampling has been carried out at one time during the day. In interpreting the results of such studies it is important to know whether dietary effects persist throughout the day. The present study provided an opportunity to explore this area and, in particular, to determine whether there were important interactions between diet and time interval after feeding. If the latter existed then sampling at only one time after feeding could be misleading. It is clear from the results in Table 5 that there were curvilinear changes in total SCFA concentration and in the molar proportion of acetate throughout the day with peaks at about $10 \mathrm{~h}$ postfeeding. When averaged across both diets the molar proportion of butyrate increased linearly $(P<0.01)$ with time interval after feeding. In contrast, the molar proportion of isovalerate fell to its nadir at $10 \mathrm{~h}$ postfeeding, with highest values late in the feeding cycle. These diurnal changes might reasonably be attributed to alterations in the substrates becoming available to, or being used by, the bacteria throughout the day, since in vitro studies have demonstrated characteristically different SCFA patterns with a range of 
substrates (Englyst et al. 1987; Goodlad \& Mathers, 1988; Mortensen et al. 1988). Another possibility is that different species of bacteria, each with its own SCFA endproducts, dominate the caecal flora at different times of the day but we are unaware of any experimental evidence to support or refute this suggestion. The rise in molar proportion of butyrate late after feeding when the most readily fermented carbohydrate is likely to be in lowest supply does not support the suggestion of Macfarlane (1991) and other mechanisms determining SCFA pattern must be active.

When miniature pigs, $40 \mathrm{~kg}$ body weight, fitted with cannulas in the caecum were fed two meals/d there were significant postprandial changes in caecal SCFA concentrations and $\mathrm{pH}$ particularly when the diet contained WB (Fleming et al. 1989). Thus, it is possible that the colons of human subjects who eat infrequent large meals (as distinct from 'nibbling' or 'grazing') will experience substantial shifts in fermentation activity throughout the day.

\section{Gastrointestinal transit time}

The time-period during which individual portions of digesta are retained in the gut or a compartment of the gut is here termed transit time and is synonymous with terms such as rate of passage or retention time (Faichney, 1975; Cummings et al. 1976b; Warner, 1981). Measurement of TT usually involves markers (indigestible substances which are present in foods or administered to the subject) and the properties of ideal markers are discussed by Kotb \& Luckey (1972). Warner (1981) has reviewed methods for measuring TT, including consideration of the mathematical treatment of results. Using Warner's (1981) categorization, the method used in the present study was repeated dose and slaughter of animals with direct calculation of TT (RKD). With this method the TT of the marker in any gut compartment is the amount of marker in the compartment divided by the rate of input of marker. Validity of the calculation requires that the animal is in approximate steady-state so that for the compartment under investigation the rates of inflow and outflow are approximately equal and constant (Warner, 1981). Where, as here, the marker is incorporated into the diet which is fed at a constant rate for several days before measurements are made, this requirement is met, but it can be seen from Fig. 2 that the time of killing after once daily feeding had a marked effect on estimates of whole tract TT. So, although on a daily basis rates of input and output of marker were constant, meal feeding leads to non-continuous marker administration which may result in widely differing estimates of TT depending on when the measurements are made. Provision of food as a series of small meals equally spaced in time throughout the day, as has frequently been done for ruminant animals (Faichney, 1975), would circumvent this difficulty.

Clearly the major diurnal changes in input and outflow of digesta from the stomach precludes the use of this approach in obtaining meaningful estimates of TT for the stomach (Fig. 1). However, the buffering effect of the stomach in storing digesta and releasing it at a more or less constant rate may mean that the time of sampling has a lesser impact on estimates of TT for more distal compartments. This was the hypothesis to be tested in the present study. For the SI, estimates of TT declined with time interval after feeding, but not nearly so markedly as for the stomach (Fig. 1). When averaged across both diets there were no significant time effects on TT estimates for either the caecum or colon (Fig, 1), but a curvilinear effect of time on large-bowel (caecum + colon) TT was detected (Table 6). The significant $(P<0.05)$ diet $\times$ time interaction for the caecum (Table 6$)$ is a warning that it may not always be safe to assume that estimates of TT for large-bowel compartments are independent of the time at which measurements are made. It seems probable that sensitivity to time of measurement will be greatest when diets of high digestibility and long caecal TT are used.

Since the classical studies of Eastwood et al. (1973) and of Payler et al. (1975) it has been 


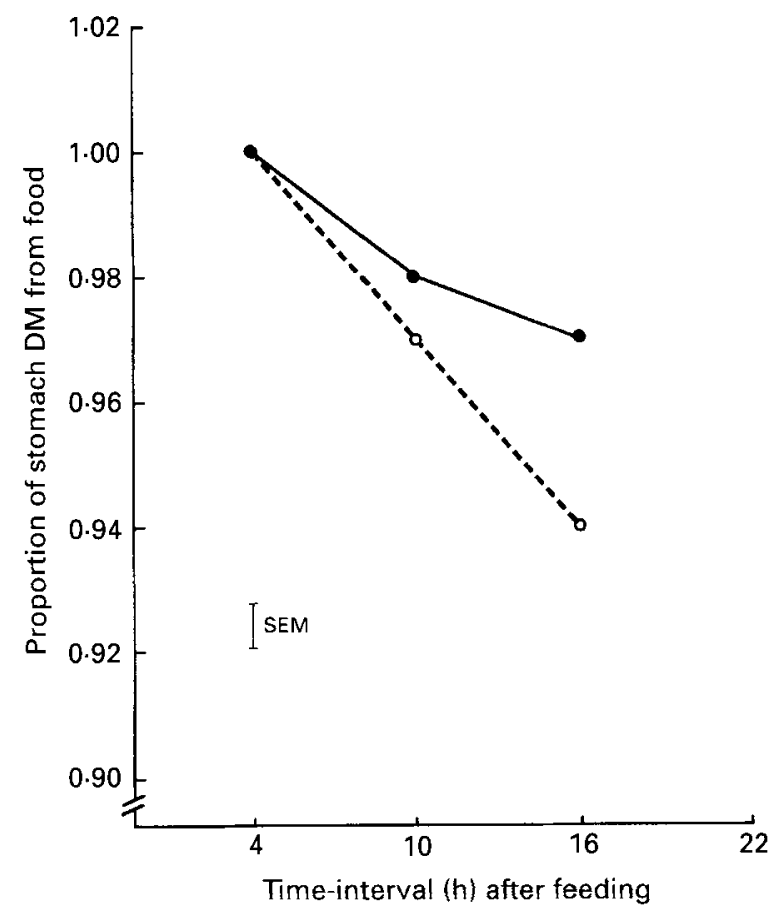

Fig. 2. Estimates of the proportion of stomach dry matter (DM) derived from ingested food at various timeintervals after feeding in rats given diets without $\left(\mathrm{O}^{-} \mathrm{O}\right)$ and with $(--) 200 \mathrm{~g}$ wheat bran $/ \mathrm{kg}$ diet. Estimates were derived by the procedure of Mathers \& Dawson (1991) and are for four rats per treatment. For details of diet composition, see Table 1.

demonstrated repeatedly in man (Müller-Lissner, 1988) and other animals (Ehle et al. 1982; Riottot et al. 1984) that adding WB to diets low in NSP reduces whole-tract TT, but it is not clear which gut compartments are most affected. McCance et al. (1953) reported faster rates of stomach emptying in human volunteers given wholemeal- compared with whitebread-based diets but in the present study there was little evidence that adding WB altered stomach emptying. When the quantity of DM in the stomach $(y ; \mathrm{g} \mathrm{DM})$ was regressed $v$. time of killing ( $x$; h after feeding), the data closely fitted straight lines with the following equations:

$$
\begin{aligned}
& \text { - WB diet }: y=11 \cdot 1\left(\text { SE 0.28) - 0.50(SE 0.020) } x, \quad r^{2} 0.98\right. \text {, } \\
& + \text { WB diet }: y=10.6(\operatorname{SE} 0.42)-0.47(\operatorname{SE} 0.029) x, \quad r^{2} 0.95 \text {. }
\end{aligned}
$$

This suggests that, in this circumstance, emptying of DM from the stomach was a zeroorder process, i.e. an equal quantity of DM was removed from the stomach per unit time, with approximately $0.5 \mathrm{~g} \mathrm{DM} / \mathrm{h}$ delivered to the duodenum for each diet. It should be noted, however, that the first measurement of stomach DM was made $4 \mathrm{~h}$ after food presentation. The intercepts on the $y$ axis were only 11.1 and $10.6 \mathrm{~g}$ for diets $-\mathrm{WB}$ and + WB respectively, which is somewhat lower than the corresponding 13.9 and $13.5 \mathrm{~g} \mathrm{DM}$ which were the mean daily intakes of the rats (Table 2 ). Therefore, early in the feeding cycle the rates of emptying of DM from the stomach were probably greater than those determined previously. Given the DM recovered in the stomach $4 \mathrm{~h}$ after feeding (Table 3 ) it may be calculated that the mean rate of stomach emptying over the first $4 \mathrm{~h}$ was $(13.9-9 \cdot 3) / 4=1.2 \mathrm{~g} / \mathrm{h}$ for diet $-\mathrm{WB}$ and, by the same reasoning, $1.3 \mathrm{~g} / \mathrm{h}$ for diet $+\mathrm{WB}$. 
In agreement with the results of Riottot et al. (1984), the major site of effect of WB on TT was the caecum where TT, averaged over all sampling times, was only $7.9 \mathrm{~h}$ ( + WB diet) compared with $12 \cdot 5 \mathrm{~h}$ for the diet without WB (Table 6). The volunteers of McCance et al. (1953) retained the marker $\mathrm{BaSO}_{4}$ in the colon for a shorter time after consuming wholemeal bread compared with white bread. It is not immediately clear why the caecum should respond in this way. Since it is the major site of fermentation in the rat one might predict that the organ would expand to accommodate the additional fermentable material provided by the WB and retain it for a sufficiently long time to maximize bacterial salvage of energy present in the WB (Stephen et al. 1987). However, caecal mass was unaffected by WB feeding (Table 3) and caecal size was much smaller than when other materials, such as cooked potatoes (Mathers \& Dawson, 1991) or pectin (Seal \& Mathers, 1989; Luick \& Penner, 1991), were fed. Large-bowel fermentation results in SCFA production and these acids may increase gut motility (Kamath et al. 1988), so accounting for the faster excretion of a marker in conventional compared with germ-free rats fed on WB (Riottot et al. 1984). Physical attributes of WB may also be important in reducing caecal TT since adding WB to a no-NSP diet fed to germ-free rats increased the rate of marker excretion (Riottot et al. 1984). Administration of inert particles to conventional dogs and pigs decreased mean retention time by reducing the number of long spike bursts (LSB) in colonic electromyograms; LSB appear to impede the passage of digesta (Cherbut \& Ruckebusch, 1985).

It should be borne in mind that the estimates of TT reported here are for the marker $\mathrm{Cr}_{2} \mathrm{O}_{3}$ and, therefore, are not necessarily identical with TT for all components of digesta. Warner (1981) concluded that there was differential retention of large particles compared with small particles and solutes in the hindgut of several species including pigs, rabbits, koala and some herbivorous birds. However, in rats fed on WB-containing diets Luick \& Penner (1991) found that the passage through the gut of a particulate marker (Crmordanted, destarched WB) was similar to that of the water-soluble Co-EDTA. In healthy human subjects the insoluble marker $\mathrm{Cr}_{2} \mathrm{O}_{3}$ and the soluble marker polyethylene glycol behave identically (Findlay et al. 1974).

\section{Coprophagy}

In physiological studies where an indigestible marker is used to determine digesta flow rates or TT in gut compartments, ingestion of faeces, and, therefore, re-ingestion of the marker could bias the estimates obtained since the actual rate of input to the gut will be greater than expected. In an earlier paper we proposed a simple method for determining the amounts of stomach DM derived from ingested food or faeces and which could, therefore, give quantitative estimates of the extent of coprophagy (Mathers \& Dawson, 1991). We have now become aware that Gidenne \& Poncet (1985) used the same calculation to estimate caecotrophy in the rabbit. In the study of Mathers \& Dawson (1991) there was little evidence of coprophagy but measurements were made at only one time of the day (4-7 h after feeding) in rats given a low-energy-dense diet. The present study provided an opportunity to examine whether there was significant coprophagy with other diets and especially at later times after feeding. At all times, more than $90 \%$ of the DM in the stomach was derived directly from food (Fig. 2). Even at $16 \mathrm{~h}$ post-feeding, when the stomach was relatively empty, the proportion of digesta DM which could be attributed to ingested faeces ranged from only 1 to $9 \%$ for individual animals. These are similar to published estimates of the extent of re-ingestion of faeces by rats fed on nutritionallycomplete diets (Hörnicke \& Björnhag, 1980; Fajardo \& Hörnicke, 1989). At its peak, $10 \mathrm{~h}$ postfeeding, re-ingested faeces contributed only $0.095 \mathrm{~g} \mathrm{DM}$ to stomach contents. At the same time the quantity of faeces-derived $\mathrm{Cr}_{2} \mathrm{O}_{3}$ was 10 and $5 \mathrm{mg}$ for diets $-\mathrm{WB}$ and $+\mathrm{WB}$, 
which corresponds to 5 and $3 \%$ respectively of daily input rate of $\mathrm{Cr}_{2} \mathrm{O}_{3}$ from the diet. Thus, it seems unlikely that the practice of coprophagy would have seriously biased the estimates of TT obtained in the present study.

The authors thank H. J. Finlayson and L. M. R. Pedroso for assistance with sample collection. J.-M.F.T. extends his gratitude to the Director, I.R.Z. Cameroon, for funding his study in Newcastle.

\section{REFERENCES}

Cheng, B.-Q., Trimble. R. P., Illman, R. J., Stone, B. A. \& Topping, D. L. (1987). Comparative effects of dictary wheat bran and its morphological components (aleurone and pericarp-seed coat) on volatile fatty acid concentrations in the rat. British Journal of Nutrition 57, 69-86.

Cherbut, C. H. \& Ruckebusch, Y. (1985). The effect of indigestible particles on digesta transit time and colonic motility in dogs and pigs. British Journal of Nutrition 53, 549-557.

Cummings, J. H., Hill, M. J., Jenkins, D. J. A., Pearson, J. R. \& Wiggins, H. S. (1976a). Changes in fecal composition and colonic function due to cereal fibre. American Journal of Clinical Nutrition 29, 1468-1473.

Cummings, J. H., Jenkins, D. J. A. \& Wiggins, H. S. (1976b). Measurement of the mean transit time of dietary residue through the human gut. Gut 17, 210-218.

Eastwood, M. A., Kirkpatrick, J. R., Mitchell, W. D., Bone, A. \& Hamilton, T. (1973). Effects of dietary supplements of wheat bran and cellulose on faeces and bowel function. British Medical Journal 4, 392-394.

Ehle, F. R., Jeraci, J. L., Robertson, J. B. \& Van Soest, P. J. (1982). The influence of dietary fiber on digestibility, rate of passage and gastrointestinal fermentation in pigs. Journal of Animal Science 55, 1071-1081.

Englyst, H. N. \& Cummings, J. H. (1985). Digestion of the polysaccharides of some cereal foods in the human small intestine. American Journal of Clinical Nutrition 42, 778-787.

Englyst, H. N., Hay, S. \& Macfarlane, G. T. (1987). Polysaccharide breakdown by mixed populations of human faecal bacteria. FEMS Microbiological Letters 45, 163-171.

Faichney, G. J. (1975). The use of markers to partition digestion within the gastrointestinal tract of ruminants. In Digestion and Metabolism in the Ruminam, pp. 277-291 [1. W. McDonald and A. C. 1., Warner, editors]. Armidale: University of New England Publishing Unit.

Fajardo, G. \& Hörnicke, H. (1989). Problems in estimating the extent of coprophagy in the rat. British Journal of Nutrition 62, 551-561.

Findlay, J. M., Mitchell, W. D., Eastwood, M. A., Anderson, A. J. B. \& Smith, A. N. (1974). Intestinal streaming patterns in chollerrhoeic enteropathy and diverticular disease. Gut 15, 207-212.

Fleming, S. E. Fitch, M. D. \& Chansler, M. W. (1989). High-fiber diets: influence on characteristics of cecal digesta including short-chain fatty acid concentrations and $\mathrm{pH}$. American Journal of Clinical Nutrition $\mathbf{5 0}$ 93-99.

Gidenne, T. \& Poncet. C. (1985). Digestion, chez le lapin en croissance, d'une ration à taux élevé de constituents pariétaux: étude méthodologique pour le calcul de digestibilité apparante, par segment digestif (Digestion of a high fibre diet in growing rabbits: methodological study for determining partial apparent digestibility). Annales de Zootechie 34, 429-446.

Goodlad, J. S. \& Mathers, J. C. (1987). Digesta flow from the ileum and transit time through the caecum of rats given diets containing graded levels of peas. Proceedings of the Nutrition Society 46, 149A.

Goodlad, J. S. \& Mathers, J. C. (1988). Effects of food carbohydrates on large intestinal fermentation in vitro. Proceedings of the Nutrition Society 47, 176A.

Goodlad, J. S. \& Mathers, J. C. (1990). Large bowel fermentation in rats given diets containing raw peas (Pisum sativum). British Journal of Nutrition 64, 569-587.

Holland, B., Welch, A. A., Unwin, I. D., Buss, D. H., Paul, A. A. \& Southgate, D. A. T. (1991). Mc Cance and Widdowson's The Composition of Foods, 5th ed. Cambridge: Royal Society of Chemistry.

Hörnicke, H. \& Björnhag, G. (1980). Coprophagy and related strategies for digesta utilization. In Digestive Physiology and Metabolism in Ruminants, pp. 707-730 [Y. Ruckebusch and P. Thivend, editors]. Lancaster: MTP Press Ltd

Kamath, P. S., Phillips, S. F. \& Zinsmeister, A. R. (1988). Short-chain fatty acids stimulate ileal motility in humans. Gastroenterology 95, 1496-1502.

Kotb, A. R. \& Luckey, T. D. (1972). Markers in nutrition. Nutrition Abstracts and Reviews 42, 813845.

Livesey, G. (1990). Energy values of unavailable carbohydrates and diets: an inquiry and analysis. American Journal of Clinical Nutrition 51, 617-637

Luick, B. R. \& Penner, M. H. (1991). Nominal response of passage rates to fiber particle size in rats. Journal of Nutrition 121, 1940-1947.

McCance, R. A., Prior, K. M. \& Widdowson, E. M. (1953). A radiological study of the rate of passage of brown and white bread through the digestive tract of man. British Journal of Nutrition 7, 98-104.

Macfarlane, G. T. (1991). Fermentation reactions in the large intestine. In Short Chain Fatty Acids: Metabolism 
and Clinical Importance, pp. 5-10 [A. F. Roche, editor]. Report of the Tenth Ross Research Conference on Medical Issues, Columbus, Ohio: Ross Laboratories.

Mathers, J. C. (1991). Digestion of non-starch polysaccharides by non-ruminant omnivores. Proceedings of the Nutrition Society 50, 161-172.

Mathers, J. C. \& Dawson, L. D. (1991). Large bowel fermentation in rats eating processed potatoes. British Journal of Nutrition 66, 313-329.

Mathers, J. C., Fernandez, F., Hill, M. J., McCarthy, P. T., Shearer, M. J. \& Oxley, A. (1990). Dietary modification of potential vitamin $\mathrm{K}$ supply from enteric bacterial menaquinones in rats. British Journal of Nutrition 63, 639-652.

Mathers, J. C. \& Fotso Tagny, J.-M. (1989). Diurnal variation in large bowel metabolism in rats given diets with and without wheat bran. Proceedings of the Nutrition Society 48, $52 \mathrm{~A}$.

Mathers, J. C., Kennard, J. \& James, O. F. W. (1993). Gastrointestinal responses to oats consumption in young adult and elderly rats: digestion, large bowel fermentation and crypt cell proliferation rates. British Journal of Nutrition 70, 567-584.

Mortensen, P. B., Holtug, K. \& Rasmussen, H. S. (1988). Short-chain fatty acid production from mono- and disaccharides in a fecal incubation system: implications for colonic fermentation of dietary fiber in humans. Journal of Nutrition 118, 321-325.

Müller-Lissner, S. A. (1988). Effect of wheat bran on weight of stool and gastrointestinal transit time: a meta analysis. British Medical Journal 296, 615-617.

Nyman, M., Asp, N.-G., Cummings, J. H. \& Wiggins, H. (1986). Fermentation of dietary fibre in the intestinal tract: comparison between man and rat. British Journal of Nutrition 55, 487-496.

Payler, D. K., Pomare, E. W., Heaton, K. W. \& Harvey, R. F. (1975). The effect of wheat bran on intestinal transit. Gut 16, 209-213.

Riottot, M., Sacquet, E. \& Leprince, C. (1984). Effect of wheat bran upon gastrointestinal transit in germ-free and conventional rats. Digestion 29, 37-41.

Seal, C. J. \& Mathers, J. C. (1989). Intestinal zinc transfer by everted gut sacs from rats given diets containing different amounts and types of dietary fibre. British Journal of Nutrition 62, 151-163.

Stephen, A. M., Wiggins, H. S. \& Cummings, J. H. (1987). Effect of changing transit time on colonic microbial metabolism in man. Gut 28, 601-609.

Stephen, A. M., Wiggins, H. S., Englyst, H. N., Cole, T. L., Wayman, B. J. \& Cummings, J. H. (1986). The effect of age, sex and level of intake of dietary fibre from wheat on large-bowel function in thirty healthy subjects. British Journat of Nutrition 56, 349-361.

Thompson, A. (1970). Rat metabolism cage. Journal of the Institute of Animal Technicians 21, 12-21.

van Dokkum, W., Pikaar, N. A. \& Thissen, J. T. N. M. (1983). Physiological effects of fibre-rich types of bread. 2. Dietary fibre from bread: digestibility by the intestinal microflora and water-holding capacity in the colon of human subjects. British Journal of Nutrition $\mathbf{5 0}, 61-74$.

Walter, D. J., Eastwood, M. A., Brydon, W. G. \& Elton, R. A. (1986). An experimental design to study colonic fibre fermentation in the rat: the duration of feeding. British Journal of Nutrition 55, 465-479.

Walter, D. J., Eastwood, M. A., Brydon, W. G. \& Elton, R. A. (1988). Fermentation of wheat bran and gum arabic in rats fed on an elemental diet. British Journal of Nutrition 60, 225-232.

Warner, A. C. I. (1981). Rate of passage of digesta through the gut of mammals and birds. Nutrition Abstracts and Reviews Series B 51, 789-820.

Wisker, E. \& Feldheim, W. (1992). Faecal bulking and energy value of dietary fibre. In Dietary Fibre - A Component of Food, pp. 233-246 [T. F. Schweizer and C. A. Edwards, editors]. London: Springer-Verlag. 